\title{
FENOMENA DEINDUSTRIALISASI DI KOTA TANGERANG DAN FAKTOR-FAKTOR YANG MEMENGARUHINYA
}

\section{PHENOMENON OF DEINDUSTRIALIZATION IN TANGERANG CITY AND INFLUENCING FACTORS}

(disubmit 08 April 2020, direvisi 07 Juni 2020, diterima 20 Juni 2020)

\author{
Reza Septian Pradana ${ }^{1}$ \\ ${ }^{1}$ Fungsional Statistisi Ahli BPS Kabupaten Aceh Jaya \\ Jalan Banda Aceh-Meulaboh Km 152, Keutapang, Calang, Aceh Jaya \\ E-mail: reza.sp@bps.go.id
}

\begin{abstract}
ABSTRAK
Penelitian ini bertujuan untuk menganalisis fenomena deindustrialisasi di Kota Tangerang dan faktor-faktor yang memengaruhinya. Penelitian ini menggunakan analisis regresi linier berganda. Hasil analisis menunjukkan bahwa adanya fenomena deindustrialisasi di Kota Tangerang yang ditandai dengan penurunan peran sektor industri terhadap perekonomian Kota Tangerang selama periode 2010-2018. Hasil estimasi dengan analisis regresi linier berganda menunjukkan bahwa keterbukaan ekonomi secara signifikan berpengaruh positif terhadap peran sektor industri terhadap perekonomian Kota Tangerang. Sebaliknya, proporsi investasi dan tingkat harga secara signifikan berpengaruh negatif terhadap peran sektor industri terhadap perekonomian Kota Tangerang. Dengan demikian, diperlukan upaya peningkatan keterbukaan ekonomi melalui kegiatan ekspor dan impor, peningkatan investasi non bangunan, dan pengendalian tingkat harga untuk mengatasi fenomena deindustrialisasi di Kota Tangerang.
\end{abstract}

Kata kunci: deindustrialisasi, investasi, keterbukaan ekonomi, tingkat harga

\section{ABSTRACT}

This study aims to analyze phenomenon of deindustrialization in Tangerang City and influencing factors. This study uses multiple regression analysis. The result of analysis shows that phenomenon of deindustrialization is occured in Tangerang City which is showed by decreasing of industry sector's share to the economy of Tangerang City during period 20102018. The result of estimation by using multiple regression analysis shows that economic openness significantly give positive influence to share of industry sector to the economy of Tangerang City. While, share of investment and price level significantly give negative influence to share of industry sector to the economy of Tangerang City. So, the effort to increase economic openness through export and import activity, increase non-building investment, and control price level to handle the phenomenon of deindustrialization in Tangerang City.

Keyword: deindustrialization, economic openness, investment, price level 


\section{PENDAHULUAN}

Kota Tangerang yang terletak di Provinsi Banten dikenal sebagai kawasan seribu industri. Hal ini dikarenakan Kota Tangerang telah menjadi pusat industri di Pulau Jawa dan memiliki lebih dari 1000 pabrik. Banyak perusahaan internasional memiliki pabrik di kota ini. Hal ini juga didukung oleh peranan Kota Tangerang sebagai pintu gerbang utama Indonesia karena Bandara Internasional Soekarno Hatta berada di wilayah Kota Tangerang.

Berdasarkan data Badan Pusat Statistik (BPS), pada tahun 2016 jumlah industri besar dan sedang (IBS) di Kota Tangerang mencapai 638 perusahaan. Jumlah IBS di Kota Tangerang paling besar apabila dibandingkan tiga kota lainnya di Provinsi Banten. Dari jumlah tersebut, 284 perusahaan masuk kedalam kategori industri besar sedangkan 354 perusahaan masuk kategori industri sedang. Industri Besar dan Sedang (IBS) di Kota Tangerang paling banyak terletak di Kecamatan Jatiuwung dimana sebanyak 121 perusahaan industri besar dan 113 perusahaan industri sedang.

Industri Mikro dan Kecil (IMK) di Kota Tangerang juga paling banyak apabila dibandingkan tiga kota lainnya di Provinsi Banten. Berdasarkan data dari Badan Pusat Statistik (BPS), pada tahun 2017-2018 jumlah industri mikro dan kecil di Kota Tangerang mencapai 11.959 perusahaan.

Teori pertumbuhan wilayah yang dikemukakan oleh Kaldor (1966) menyebutkan bahwa sektor industri manufaktur sebagai sektor sekunder merupakan mesin pertumbuhan (engine of growth) dalam sistem perekonomian bagi suatu negara (Dasgupta dan Singh, 2006).

Keberadaan perusahaan industri juga berperan dalam mengurangi tingkat pengangguran karena mampu menyerap banyak tenaga kerja. Berdasarkan data Badan Pusat Statistik (BPS), dari 638 perusahaan IBS di Kota Tangerang telah mampu menyerap tenaga kerja sebanyak 189.036 orang. Kemudian, dari 11.959 perusahaan IMK telah mampu menyerap tenaga kerja sebanyak 40.252 orang.

Banyaknya industri di Kota Tangerang seharusnya dapat meningkatkan nilai tambah sektor industri di Kota Tangerang sehingga menambah peran sektor industri terhadap perekonomian di Kota Tangerang. Berdasarkan data dari Badan Pusat Statistik (BPS), Produk Domestik Regional Bruto (PDRB) Atas Dasar Harga Konstan (ADHK) Sektor Industri Manufaktur sebesar 107,26 trilyun rupiah pada tahun 2018 dan mengalami pertumbuhan sebesar 3,24 persen apabila dibandingkan tahun 2017 yang mencapai 101,27 trilyun rupiah. Namun demikian, laju PDRB sektor industri pada tahun 2018 mengalami penurunan apabila dibandingkan tahun 2017 yang mencapai 3,62 persen. Kontribusi PDRB sektor industri manufaktur terhadap PDRB Kota Tangerang juga menunjukkan penurunan dimana pada tahun 2018 mencapai 29,35 persen sedangkan pada tahun 2017 mencapai 30,19 persen.

Penurunan kontribusi sektor industri cukup mengkhawatirkan mengimgat sektor industri sangat berperan dalam mendorong pertumbuhan ekonomi, pengentasan kemiskinan, dan penciptaan lapangan kerja untuk mengurangi tingkat pengangguran. Menurut Kustanto, et al (2012), penurunan kontribusi dan pertumbuhan sektor industri ini mengarah pada suatu gejala deindustrialisasi yaitu proses perubahan sosial dan ekonomi yang disebabkan oleh penurunan kapasitas 
atau aktivitas industri dalam suatu wilayah. Blackaby (1979) dalam Jalilian dan Weiss (2000) mendefiniskan deindustrialisasi sebagai penurunan nilai tambah riil sektor manufaktur atau penurunan kontribusi sektor manufaktur dalam pendapatan nasional. World Bank (1994) dalam Jalilian dan Weiss (2000) mendefinisikan deindustrialisasi sebagai penurunan tidak sementara kontribusi sektor manufaktur yang dapat menurunkan efisiensi ekonomi dan menyebabkan pertumbuhan ekonomi berjalan lebih lambat. Menurut Rowthorn dan Coutts (2004) dalam Dewi (2010), deindustrialisasi ditandai dengan penurunan kontribusi sektor manufaktur pada perekonomian nasional. Rowthorn dalam Metinara (2011) membedakan deindustrialisasi menjadi dua macam yaitu deindustrialisasi positif dan deindustrialisasi negatif.

Deindustrialisasi positif merupakan dampak yang terjadi karena perekonomian telah mengalami kedewasaan (maturity) dalam pembangunan ekonomi. Dengan pembangunan ekonomi yang meningkatkan pendapatan per kapita, peran tenaga kerja sektor pertanian mengalami penurunan dan peran tenaga kerja sektor manufaktur meningkat sampai pada tingkat tertinggi dalam pembangunan yang dicapai. Namun, di sisi lain terjadi peningkatan pendapatan per kapita dari peningkatan peran sektor jasa seiring dengan peningkatan biaya dalam sektor manufaktur akibat kenaikan upah tenaga kerja. Hal ini terjadi sebagai konsekuensi dari tingkat pertumbuhan produktivitas di sektor manufaktur relatif lebih tinggi dibandingkan dengan sektor jasa dan adanya perubahan dalam pola konsumsi yang terjadi selama pembangunan ekonomi. Perubahan pola konsumsi ini lebih disebabkan oleh perbedaan elastisitas pendapatan dari permintaan antar sektor.

Deindustrialisasi negatif merupakan fenomena patologis (pathological phenomenon), yaitu terjadi ketidakseimbangan struktural dalam perekonomian yang mencegah suatu bangsa mencapai pertumbuhan yang full employment. Keadaan ini terjadi karena memburuknya kinerja sektor manufaktur dan melambatnya pertumbuhan output dan produktivitas sektor manufaktur yang mengakibatkan menurunnya daya saing sehingga perekonomian semakin memburuk. Pengangguran dari sektor manufaktur yang dihasilkan dari adanya deindustrialisasi negatif tidak dapat terserap di sektor jasa akibat situasi perekonomian yang melambat. Dengan demikian, deindustrialisasi positif dikaitkan dengan meningkatnya pendapatan riil dan lapangan kerja penuh (full employment), sementara deindustrialisasi negatif dikaitkan dengan stagnasi pendapatan riil dan meningkatnya pengangguran (Alderson, 1999).

Berdasarkan data dari Badan Pusat Statistik (BPS), selama periode 20102018, share PDRB sektor industri terhadap PDRB Kota Tangerang terus menunjukkan penurunan. Pada tahun 2010, share PDRB Sektor Industri terhadap PDRB Kota Tangerang mencapai 42,91 persen dan mengalami penurunan secara terus menerus hingga mencapai 29,35 persen pada tahun 2018 . Hal ini menjadi indikasi adanya fenomena deindustrialisasi di Kota Tangerang. Oleh karena itu, diperlukan serangkaian upaya antisipasi agar kondisi deindustrialisasi tidak berlanjut dan berdampak buruk pada perekonomian Kota Tangerang. Analisis faktor-faktor penyebab deindustrialisasi 
menjadi penting untuk dilakukan agar dapat dirumuskan berbagai kebijakan untuk mendorong kembali peranan sektor industri dalam perekonomian melalui serangkaian kebijakan reindustrialisasi (Kustanto, et al (2012)).

Teori Marx tentang penurunan keuntungan (profit) suatu industri dianggap sebagai awal mula dari munculnya teori deindustrialisasi (Rowthorn, 1992). Teori tersebut menyebutkan bahwa inovasi teknologi dapat membuat proses produksi menjadi lebih efisien sehingga dapat meningkatkan produktivitas. Pada saat yang bersamaan, inovasi teknologi dapat menyebabkan pengurangan jumlah pekerja karena pekerja digantikan dengan mesin sehingga kapasitas penggunaan kapital meningkat. Apabila pekerja diasumsikan dapat memberikan nilai tambah baru, semakin besar penggunaan kapital akan menghasilkan nilai tambah dan surplus yang lebih kecil dibandingkan penambahan pekerja. Penambahan pekerja menyebabkan rata-rata profit industri akan menurun dalam jangka panjang. Oleh karenanya, sebuah industri perlu melakukan inovasi teknologi sebagai investasi kapital serta mengembangkan kemampuan pekerjanya sebagai investasi human capital untuk mengantisipasi terjadinya deindustrialisasi negatif (Metinara, 2011).

Reisman (2002) dalam Dewi (2010) menemukan bahwa kenaikan tingkat harga (inflasi) turut berkontribusi dalam terjadinya deindustrialisasi. Inflasi menyebabkan investasi menjadi lebih mahal dan profit yang diharapkan menjadi berkurang.

Singh (1977) menyatakan bahwa untuk menganalisis adanya industrialisasi dan deindustrialisasi dalam kasus perekonomian terbuka, tidak cukup hanya dengan menganalisis karakteristik perekonomian domestik saja melainkan harus menganalisis juga interaksi dengan negara lainnya. Peran pelaku ekonomi luar negeri sebagai penyedia bahan baku impor dan upaya untuk memperluas pemasaran hasil produksi industri.

Penelitian terkait deindustrialisasi sudah banyak dilakukan. Jakti dn Sumarwan (2005) menunjukkan bahwa dalam jangka panjang pendapatan per kapita, pangsa PMTDB dalam PDB, pangsa nilai ekspor produksi industri dalam PDB, pangsa neraca perdagangan produk industri dalam PDB, dan pangsa nilai impor barang modal dalam PDB berdampak positif terhadap kontribusi sektor industri dalam PDB.

Rowthorn dan Ramaswamy (1997) menggunakan analisis regresi untuk menghitung dampak berbagai faktor pada pangsa tenaga kerja sektor industri pada beberapa kelompok negara industri. Deindustrialisasi pada beberapa studi seperti Palma (2007), Rowthorm dan Ramaswamy (1997), Mickiewicz dan Zalewska (2002), Ainginger (2003), Watts dan Valadkhani (2001) lebih banyak disoroti dari penurunan pangsa tenaga kerja yang bekerja pada sektor industri. Penurunan pangsa tenaga kerja biasanya seiring dengan turunnya pangsa output sektor industri terhadap total output nasional suatu perekonomian. Penurunan pangsa tenaga kerja dan pangsa sektor industri dalam pembentukan PDB mengarah pada kondisi deindustrialisasi. Model yang dikembangkan Rowthorn dan Ramaswamy (1997) mengikuti pendekatan umum yang digunakan oleh Rowthorn dan Wells (1987) yang telah dimodifikasi untuk melihat pengaruh 
pembentukan capital dan perdagangan utara-selatan.

Penelitian yang dilakukan oleh Putra (2012) dan Pratama (2012) menunjukkan bahwa secara simultan investasi, tingkat harga (Indeks Harga Konsumen), dan keterbukaan ekonomi (openness) secara signifikan berpengaruh terhadap fenomena deindustrialisasi.

Berdasarkan pemikiran diatas, diperlukan suatu analisis untuk mengidentifikasi fenomena deindustrialisasi di Kota Tangerang dan faktor-faktor yang memengaruhinya. Dengan demikian, diperoleh informasi terkait upaya yang dapat dilakukan untuk mengatasi permasalahan deindustrialisasi di Kota Tangerang.

Ada tiga hipotesis yang digunakan dalam penelitian ini. Pertama, proporsi investasi dan keterbukaan ekonomi berpengaruh positif terhadap peran sektor industri terhadap perekonomian Kota Tangerang. Kedua, tingkat harga bepengaruh negatif terhadap peran sektor industri terhadap perekonomian Kota Tangerang.

\section{METODE PENELITIAN}

Metode analisis yang digunakan dalam penelitian ini adalah analisis regresi linier berganda. Analisis regresi linier berganda digunakan untuk membentuk model yang dapat menjelaskan seberapa besar pengaruh variabel bebas terhadap variabel dependen.

Variabel dependen dalam penelitian ini yaitu peran sektor industri terhadap perekonomian Kota Tangerang sedangkan variabel bebas dalam penelitian ini yaitu proporsi investasi, keterbukaan ekonomi, dan tingkat harga. Seluruh data yang digunakan dalam penelitian ini berasal dari Badan Pusat Statistik (BPS) Kota Tangerang.

Model yang akan digunakan dalam penelitian ini adalah sebagai berikut:

$$
\begin{aligned}
\text { Outshare }_{t}= & \alpha+\beta_{1} \text { PMTBshare }_{t} \\
& +\beta_{2} \text { Openness }_{t} \\
& +\beta_{3} \text { IHK }_{t}+e_{t}
\end{aligned}
$$

dimana:

$$
\begin{aligned}
\text { Outshare }_{t}= & \text { Peran sektor industri } \\
& \text { terhadap perekonomian } \\
& \text { Kota Tangerang yang } \\
& \text { diproksi dengan share } \\
& \text { PDRB Sektor Industri } \\
& \text { terhadap PDRB Kota } \\
& \text { Tangerang periode } t \\
& \text { (persen) } \\
= & \text { Intersep } \\
= & \text { Koefisien Regresi } \\
& \text { Variabel Independen } \\
\beta_{1}, \beta_{2}, \beta_{3} & \text { Proporsi investasi yang } \\
\text { PMTBshare }_{t}= & \text { diproksi dengan share } \\
& \text { PMTB terhadap PDRB } \\
& \text { Kota Tangerang periode } \\
& t \text { (persen) } \\
= & \text { tingkat keterbukaan } \\
& \text { ekonomi yang diproksi } \\
& \text { dengan share ekspor } \\
& \text { dan impor terhadap } \\
& \text { PDRB Kota Tangerang } \\
\text { Openness } & \text { periode } t \text { (persen) } \\
= & \text { Tingkat Harga yang } \\
& \text { diproksi dengan Indeks } \\
& \text { Harga Konsumen } \\
= & \text { periode } t \text { (poin) } \\
= & \text { residual periode } t \\
& \text { tahun 2010, 2011, ..... } \\
\text { IHK }_{t} & \text { 2018 }
\end{aligned}
$$

\section{HASIL DAN PEMBAHASAN}


Fenomena Deindustrialisasi di Kota Tangerang dan Faktor-Faktor yang Memengaruhinya

Menurut Rowthorn dan Coutts (2004) dalam Dewi (2010), deindustrialisasi ditandai dengan penurunan kontribusi sektor industri terhadap perekonomian. Produksi Domestik Regional Bruto (PDRB) menrupakan salah satu indikator untuk mengetahui kondisi perekonomian suatu wilayah.

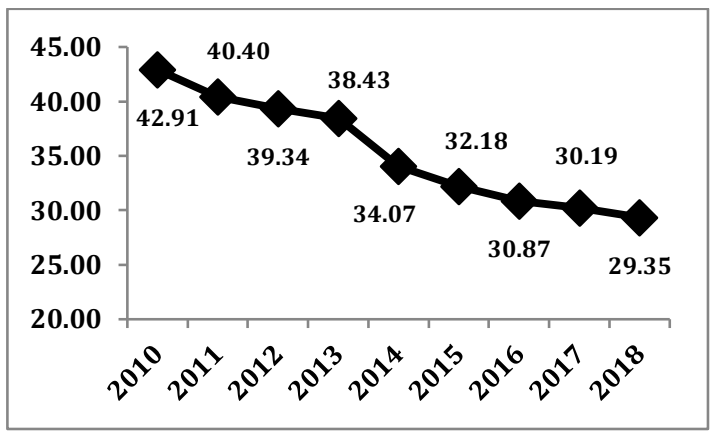

Sumber: BPS, diolah

\section{Gambar 1 Perkembangan Share PDRB Sektor Industri terhadap PDRB Kota Tangerang Tahun 2010-2018 (persen)}

Selama periode 2010-2018, share PDRB Sektor Industri terhadap PDRB Kota Tangerang terus mengalami penurunan. Pada tahun 2010, share PDRB Sektor Industri terhadap PDRB Kota Tangerang mencapai 42,91 persen namun pada tahun 2018 hanya mencapai 29,35 persen. Hal ini menjadi indikasi terjadinya deindustrialisasi di Kota Tangerang. Penurunan kontribusi/ peran sektor industri terhadap perekonomian Kota Tangerang terjadi pada tahun 2014 dimana penurunannya mencapai 4,36 persen.

Kenaikan tingkat harga yang diukur dengan kenaikan Indeks Harga Konsumen diduga turut memengaruhi penurunan nilai tambah sektor industri. Kenaikan tingkat harga mengakibatkan biaya produksi mengalami kenaikan sehingga profit perusahaan mengalami penurunan. Hal ini selanjutnya dapat berdampak pada penurunan nilai tambah sektor industri.

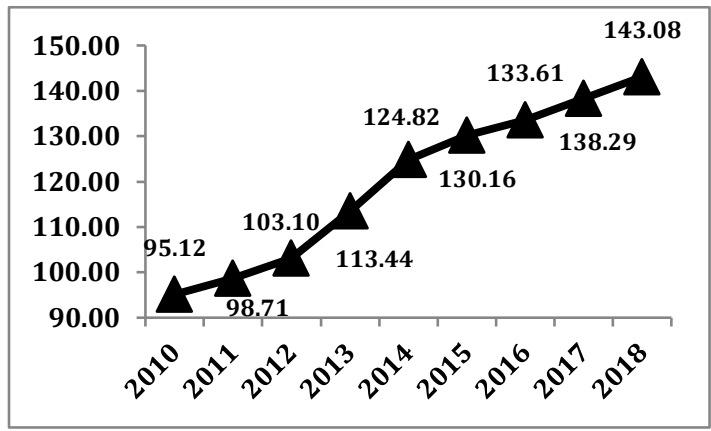

Sumber: BPS, diolah

Gambar 2 Perkembangan Indeks Harga Konsumen (IHK) Kota Tangerang Tahun 2010-2018

Gambar 2 memperlihatkan perkembangan tingkat harga tiap tahunnya pada periode 2010-2018. Berlawanan dengan pergerakan Share PDRB Sektor Industri terhadap PDRB Kota Tangerang, tingkat harga di Kota Tangerang terus mengalami kenaikan selama periode 2010-2018. Pada tahun 2010, IHK Kota Tangerang mencapai 95,12 kemudian pada tahun 2018 IHK Kota Tangerang telah mencapai 143,08. Kenaikan Indeks Harga Konsumen secara terus menerus menunjukkan bahwa telah terjadi inflasi di Kota Tangerang selama periode 2018. Inflasi/ pertumbuhan IHK tertinggi terjadi pada tahun 2014 sebesar 10,03 persen. Hal ini serupa dengan penurunan tertinggi kontribusi sektor industri yang terjadi pada tahun 2014.

Dalam perkembangannya, sektor industri juga memerlukan investasi dalam peningkatan kapasitas produksinya. Semakin besar proporsi investasi yang 
diukur dengan rasio Pembentukkan Modal Tetap Bruto (PMTB) terhadap PDRB Kota Tangerang, semakin besar juga peluang industri dalam peningkatan kapasitas produksinya karena bertambahnya mesin-mesin industri. Selanjutnya, ini akan meningkatkan nilai tambah sektor industri di Kota Tangerang.

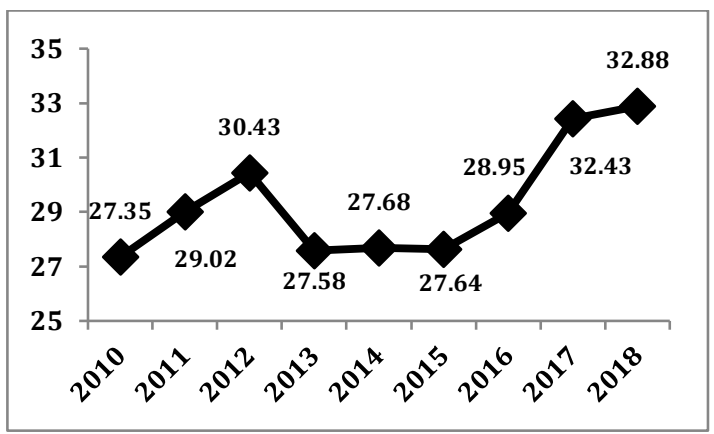

Sumber: BPS, diolah

\section{Gambar 3 Perkembangan Proporsi PMTB Terhadap PDRB Kota Tangerang Tahun 2010-2018 (persen)}

Berdasarkan gambar 3, proporsi PMTB terhadap PDRB Kota Tangerang secara umum menunjukkan trend menaik selama periode 2010-2018. Pada tahun 2010, proporsi PMTB mencapai 27,35 persen. Kemudian, pada tahun 2018 proporsi PMTB mencapai 32,88 persen. Proporsi PMTB sempat mengalami penurunan pada tahun 2013 dan 2015. Penurunan tertinggi terjadi pada tahun 2013 yakni sebesar 2,85 persen. Pada tahun 2016, proporsi PMTB kembali mengalami kenaikan. Kenaikan tertinggi terjadi pada tahun 2017.

Keterlibatan pelaku ekonomi luar negeri juga diduga turut memberikan andil terhadap perkembangan sektor industri. Keterbukaan ekonomi (Openness) ditinjau berdasarkan kegiatan ekspor dan impor. Ekspor diperlukan guna meningkatkan pangsa pasar produk sektor industri. Kemudian, impor diperlukan dalam rangka pemenuhan bahan baku berkualitas yang diperlukan sektor industri.

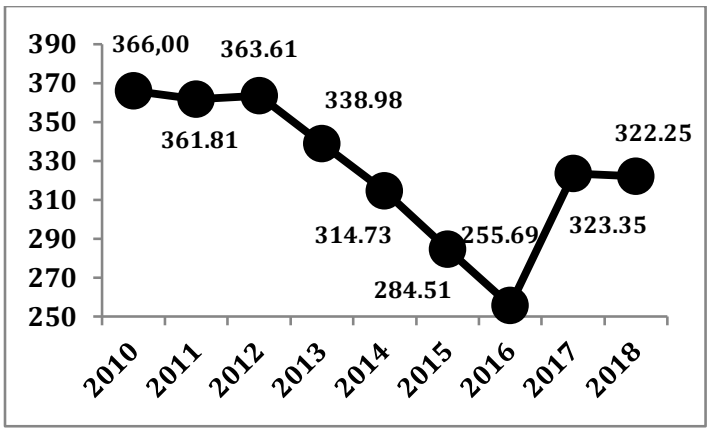

Sumber: BPS, diolah

$\begin{array}{rlr}\text { Gambar } 4 \quad \begin{array}{l}\text { Perkembangan } \\ \text { Keterbukaan }\end{array} & \text { Tingkat } \\ & \text { Ekonomi } \\ & \text { Tangenness) } & \text { Kota } \\ & 2018 \text { (persen) }\end{array}$

Dari gambar 4, diperoleh informasi bahwa tingkat keterbukaan ekonomi Kota Tangerang secara umum menunjukkan penurunan dimana pada tahun 2010 mencapai 366,00 persen sedangkan pada tahun 2018 sudah mencapai 322,25 persen. Penurunan tingkat keterbukaan ekonomi Kota Tangerang mulai terjadi pada tahun 2011 namun kembali naik pada tahun 2012. Penurunan tingkat keterbukaan ekonomi Kota Tangerang kembali terjadi pada tahun 2013 hingga tahun 2016. Pada tahun 2017, tingkat keterbukaan ekonomi mengalami kenaikan tertinggi namun kembali menurun pada tahun 2018. Penurunan tertinggi terjadi pada tahun 2015 .

\section{Pembentukkan Model Terbaik dan Pengujian Asumsi Dasar}

Dengan menggunakan software Eviews 9, model terbentuk dalam penelitian ini adalah sebagai berikut: 


$$
\begin{aligned}
\text { Outshare }_{t}= & 62,00-0,44^{*} \text { PMTBShare }_{t} \\
& +0,03^{*} \text { Openness }_{t} \\
& -0,20^{*} \text { IHK }_{t}+e_{t}
\end{aligned}
$$

Adjusted $R^{2}=0,9888$

Prob F-Stat $=0,000008$

Keterangan:

* signifikan pada alpha 5 persen

Tabel 1

Hasil Pengujian Signifikansi Seluruh Variabel Bebas Model Terbaik

\begin{tabular}{crc}
\hline Variabel & t-statistic & P-value \\
\hline PMTBshare $_{t}$ & $-2,9118$ & 0,0333 \\
Openness $_{t}$ & 3,0219 & 0,0294 \\
IHK $_{t}$ & $-7,1841$ & 0,0008 \\
\hline
\end{tabular}

Gujarati (2004) mengatakan bahwa semua statistik parametrik termasuk regresi linier bearganda mensyaratkan asumsi-asumsi yang harus dipenuhi sebelum estimasi model dilakukan. Pelanggaran terhadap satu atau beberapa asumsi saja mungkin akan menyebabkan masalah yang serius seperti koefisien regresi menjadi bias, standar error menjadi bias dan nilai $R^{2}$ serta pengujian signifikansi menjadi tidak tepat/ misleading. Dengan demikian, perlu dilakukan pengujian terhadap asumsiasumsi tersebut.

Model yang mampu menghasilkan penduga yang BLUE (Best Linear Unbiased Estimator) harus memenuhi asumsi kenormalan, homoskedastisitas, non-autokorelasi, dan nonmultikolinearitas. Berikut ini ringkasan hasil pengujian normalitas, homoskedastisitas, dan non-autokrelasi dengan menggunakan software Eviews 9.

Tabel 2
Hasil Pengujian Beberapa Asumsi Dasar pada Model Terbaik

\begin{tabular}{lc}
\hline \multicolumn{1}{c}{ Pengujian } & $P$-value \\
\hline Jarque-Bera & 0,7890 \\
Breusch-Pagan-Godfrey & 0,1354 \\
Lagrange Multiplier & 0,0839 \\
\hline
\end{tabular}

Asumsi Normalitas dari model yang terbentuk telah terpenuhi. Hal ini dapat dibuktikan dengan nilai probabilitas $(P$ value) dari Jarque-Bera test lebih besar dari alpha 0,05 (terima $\mathrm{H}_{0}$ ). Dengan demikian, dapat dinyatakan bahwa residual dari model yang terbentuk berdistribusi nomal.

Varians residual dari model yang terbentuk juga bersifat homoskedastis. Hal ini dibuktikan dengan nilai probabilitas (P-value) dari BreuschPagan-Godfrey test lebih besar dari alpha 0,05 (terima $\mathrm{H}_{0}$ ).

Pada model yang terbentuk diatas, tidak terjadi autokorelasi. Hal ini dibuktikan dengan nilai probabilitas $(P$ value) dari Lagrange Multiplier test (LM test) lebih besar dari alpha 0,05 (terima $\mathrm{H}_{0}$ ). Dengan kata lain, asumsi nonautokorelasi terpenuhi.

Pengujian asumsi nonmultikolinieritas pada penelitian ini menggunakan uji formal yakni berdasarkan nilai Variance Inflation Factor (VIF). Dengan menggunakan software SPSS 22, diperoleh hasil pengujian non-multikolinearitas sebagai berikut:

Tabel 3

Hasil Pengujian Non-Multikolinearitas pada Variabel Bebas Model Terbaik

\begin{tabular}{cc}
\hline Variabel & VIF \\
\hline PMTBshare $_{t}$ & 1,991 \\
Openness $_{t}$ & 8,835
\end{tabular}




\begin{tabular}{cc}
$I H K_{t}$ & 7,049 \\
\hline
\end{tabular}

Asumsi Non-Multikolinearitas atas seluruh variabel bebas yang digunakan dalam model sudah terpenuhi. Hal ini dibuktikan dengan nilai Variance Inflation Factor (VIF) untuk seluruh variabel jauh lebih kecil dari 10 sehingga dapat disimpulkan tidak terjadi hubungan antara variabel bebas yang masuk ke dalam model.

Berdasarkan uji asumsi dasar di atas, dapat disimpulkan bahwa model yang terbentuk merupakan model terbaik. Model ini dapat digunakan untuk menganalisis pengaruh proporsi investasi, keterbukaan ekonomi, dan tingkat harga terhadap peran sektor industri terhadap perekonomian Kota Tangerang.

Faktor-Faktor yang Memengaruhi Deindustrialisasi di Kota Tangerang Periode 2010-2018

Nilai Adjusted $R$-Square yang diperoleh sebesar 0,9888 yang berarti bahwa variasi yang terjadi pada share PDRB sektor industri terhadap PDRB Kota Tangerang dapat dijelaskan oleh share PMTB terhadap PDRB Kota Tangerang, Tingkat Keterbukaan Ekonomi, dan tingkat harga (Indeks Harga Konsumen) Kota Tangerang sebesar 98,88 persen sedangkan sisanya sebesar 1,12 persen dijelaskan oleh variabel lain yang tidak masuk di dalam model.

Secara overall, proporsi investasi, keterbukaan ekonomi, dan tingkat harga secara signifikan berpengaruh terhadap peran sektor industri dalam perekonomian Kota Tangerang. Hal ini ditunjukkan dengan nilai probabilitas uji $F$-statistic sebesar 0,000008 yang lebih kecil dari alpha 0,05 .
Secara parsial, variabel proporsi investasi, keterbukaan ekonomi, dan tingkat harga signifikan di dalam model. Hal ini ditunjukkan dengan nilai $p$-value uji $t$-statistic untuk kedua variabel bebas tersebut lebih kecil dari alpha 0,05. Dengan demikian, dapat disimpulkan bahwa proporsi investasi, keterbukaan ekonomi, dan tingkat harga secara signifikan berpengaruh terhadap peran sektor industri terhadap perekonomian Kota Tangerang.

Nilai koefisien proporsi investasi sebesar -0,44 memiliki arti bahwa dengan tingkat kepercayaan 95 persen, jika proporsi investasi bertambah sebesar 1 persen maka peran sektor industri terhadap perekonomian Kota Tangerang akan berkurang sebesar 0,44 persen. Pengaruh negatif proporsi investasi terhadap peran sektor industri tidak sesuai dengan teori yang dihipotesiskan. Hingga saat ini, investasi/ Pembentukkan Modal Tetap Bruto (PMTB) Kota Tangerang masih didominasi oleh non bangunan. Berdasarkan data Badan Pusat Statistik (BPS), distribusi persentase PMTB bangunan Kota Tangerang sebesar 21,11 persen sedangkan PMTB non bangunan sebesar 9,86 persen pada tahun 2018 . Dalam peningkatan nilai tambah sektor industri, peningkatan investasi non bangunan seperti mesin-mesin industri sangat diperlukan karena berkaitan erat dengan peningkatan kapasitas produksi. Selain itu, peningkatan investasi sebaliknya diiringi dengan peningkatan human capital baik dari segi kualitas maupun kuantitas. Investasi dalam bentuk non bangunan seperti mesin-mesin industri memerlukan Sumber Daya Manusia (SDM) yang berkualitas dalam mengoperasikannya karena seiring perkembangan zaman, inovasi teknologi 
dalam mesin-mesin industri turut berkembang.

Nilai koefisien tingkat keterbukaan ekonomi sebesar 0,03 memiliki arti dengan tingkat kepercayaan 95 persen, jika tingkat keterbukaan ekonomi naik 1 persen maka peran sektor industri terhadap perekonomian Kota Tangerang naik 0,03 persen. Pengaruh positif tingkat keterbukaan ekonomi terhadap peran sektor industri sesuai dengan teori yang dihipotesiskan. Dalam perekonomian terbuka, diperlukan adanya keterlibatan pelaku ekonomi luar negeri. Semakin tinggi tingkat keterbukaan suatu daerah maka semakin luas pangsa pasar produk yang dihasilkan sektor industri. Ditambah lagi, lokasi bandar udara internasional Soekarno Hatta terletak di Kota Tangerang sehingga memperlancar arus distribusi barang hasil produksi sektor industri. Keadaan ini juga menunjukkan bahwa suatu daerah yang lebih terbuka dalam perekonomiannya akan lebih baik dibandingkan perekonomian yang tertutup. Semakin meningkat keterbukaan ekonomi (openness) suatu daerah mengindikasikan bahwa kinerja perdagangan daerah tersebut meningkat. Dengan meningkatnya kinerja perdagangan terutama ekspor manufaktur, secara tidak langsung mengindikasikan bahwa produk-produk industri lokal dapat bersaing. Hal ini secara tidak langsung menyebabkan proporsi pekerja industri semakin meningkat seiring dengan meningkatnya demand produk industri.

Nilai koefisien tingkat harga sebesar 0,20 memiliki arti bahwa dengan tingkat kepercayaan 95 persen, jika tingkat harga naik sebesar 1 persen maka peran sektor industri terhadap perekonomian Kota Tangerang turun sebesar sebesar 0,20 persen. Pengaruh negatif tingkat harga terhadap peran sektor industri sesuai dengan teori yang dihipotesiskan. Kenaikan harga akan mengakibatkan harga input/ biaya antara sektor industri mengalami peningkatan. Selain itu, kenaikan tingkat harga juga mengakibatkan investasi menjadi lebih mahal. Akibatnya, profit yang diharapkan industri menjadi berkurang. Kemudian, ini akan berdampak pada penurunan nilai tambah sektor industri.

\section{KESIMPULAN}

Selama periode 2010-2018, share PDRB Sektor Industri terhadap PDRB Kota Tangerang terus mengalami penurunan. Hal ini mengindikasikan terjadinya deindustrialisasi di Kota Tangerang.

Tingkat keterbukaan ekonomi Kota Tangerang secara umum mengalami kenaikan selama periode 2010-2018. Trend yang cenderung menaik ini seiring dengan kenaikan share PDRB Sektor Industri terhadap PDRB Kota Tamgerang. Sebaliknya, perkembangan proporsi investasi dan tingkat harga (IHK) cenderung berlawanan dengan perkembangan share PDRB Sektor Industri terhadap PDRB Kota Tangerang dimana keduanya menunjukkan trend menurun.

Proporsi investasi secara signifikan berpengaruh negatif terhadap peran sektor industri. Hal ini mengindikasikan peningkatan proporsi investasi dapat menurunkan share nilai tambah Sektor Industri di Kota Tangerang. Dengan demikian, peningkatan investasi non bangunan seperti mesin-mesin industri perlu dilakukan dan diiringi dengan peningkatan kualitas human capital di Sektor Industri. Peningkatan kualitas human capital dapat dilakukan dengan 
memberikan pelatihan pada seluruh pekerja di sektor industri baik dari sisi manajerial maupun teknis.

Tingkat keterbukaan ekonomi secara signifikan berpengaruh positif terhadap peran sektor industri. Hal ini mengindikasikan kegiatan ekspor dan impor mampu meningkatkan share nilai tambah Sektor Industri di Kota Tangerang sehingga dapat terhindar dari fenomena deindustrialisasi. Dengan demikian, peningkatan keterbukaan ekonomi melalui kegiatan ekspor dan impor perlu dilakukan.

Tingkat harga secara signifikan berpengaruh negatif terhadap peran sektor industri. Ini berarti kenaikan harga secara terus menerus dapat menyebabkan terjadinya deindustrialisasi di Kota Tangerang. Dengan demikian, diperlukan upaya pemerintah dalam pengendalian harga di Kota Tangerang.

\section{DAFTAR PUSTAKA}

Aiginger, K. (2003). De-Industrialisation and the Lisbon Agenda. Austrian Institute of Economic Research, University of Linz.

Alderson, A. (1999). Explaining Deindustrialization:

Globalization, Failure, or Success?. American Sociological Review Vol. 64 (5): 701-721.

Dasgupta S, Singh A. (2006). Manufacturing, Services and Premature Deindustrialization in Developing Countries: A Kaldorian Analysis. Research Paper United Nation University No. 2006/49: 1-18.

Dewi, D.A. (2010). Deindustrialisasi di Indonesia 1983-2008: Analisis
Dengan Pendekatan Kaldorian. Bogor: IPB.

Gujarati, Damodar N. (2004). Basic Econometrics: Forth Edition. Mc. Graw Hill Companies.

Jakti, D.K., Suwarman, W. (2005). Faktor-Faktor yang Mendorong Terjadinya Proses Deindustrialisasi di Indonesia. Jakarta: Universitas Indonesia.

Jalalian H, Weiss J. (2000). Deindustrialisation in Sub-Saharan: Myth or Crysis?. Journal of American Economies Volume 9 Number 1: 24-43.

Kustanto H, et al. (2012). Reindustrialisasi dan Dampaknya Terhadap Ekonomi Makro Serta Kinerja Sektor Industri di Indonesia. Jurnal Riset Industri Vol. VI No.1: 97-115.

Metinara, Susi. (2011). Faktor-Faktor Yang Mempengaruhi

Deindustrialisasi Di Indonesia Tahun 2000-2009. Bogor : IPB

Mickiewicz, T. dan Zalewska, A. (2002). Deindustrialisation, Lesson from the Structural Outcomes of PostCommunist Transition. William Davidson Institute Working paper No. 463, Januari 2002.

Palma, J.G. (2007). Four Sources of "Deindustrialization" and A New Concept of the "Dutch Disease".

Pratama, J. (2012). Fenomena Deindustrialisasi di Provinsi Jawa Timur Tahun 1990-2010 Berdasarkan Model Vector Error Correction Mechanism. Jakarta: STIS.

Putra, R.T. (2012). Fenomena Deindustrialisasi di Provinsi 
Sulawesi Tenggara Tahun 19902010 Berdasarkan Metode Error Correction Model (ECM). Jakarta: STIS.

Rowthorn R. (1992). Productivity and American Leadership - A Review. Review of Income and Wealth Vol. 38, No. 4: 47-96.

Rowthorn, R., Wells, J.R. (1987). Deindustrialisation and Foreign Trade. Cambridge University Press.

Rowthorn, R., Ramaswamy, R. (1997). Deindustrialisation: Causes and Implications. IMF Working Paper
WP/97/42. International Monetary Fund, Washington D.C.

Singh A. (1977). UK Industry and The World Economy: A Case of Deindustrialization?. Cambridge Journal of Economics Volume 1 Number 2: 113-136.

Watts, M., Valadkani, A. (2001). The Impact of Deindustrialization on Employment Outcomes in Australia, Japan and the USA. Centre of Full Employment and Equity, The University of Newcastle, Australia. 